\title{
Mechanisims of asthma and allergic disease - 1064. Interleukin 31 (IL 31) serum levels in atopic dermatitis patients
}

\author{
Noor Suryani Mohd Ashari ${ }^{1 *}$, Siti Nur Syuhada', M Mustaffa', Wan Zuraida Wah', AR Azriani ${ }^{1}$, I Zulrushydi \\ From 2nd WAO International Scientific Conference (WISC 2012) \\ Hyderabad, India. 6-9 December 2012
}

\section{Background}

Atopic dermatitis is a common chronic skin disorder which is a subset of atopy. Atopy refers to a genetic predisposition to respond immunonologically to allergens which are generally harmless, causingover production of immunoglobulin E (IgE) antibodies. IgE synthesis is dependent on the activation of CD4+ Th2 subset and their secretion of cytokines including IL 4 and IL 13. This study was done to compare between IL 31 serum levels in normal controls and atopic dermatitis patients in Kelantan, Malaysia.

\section{Methods}

This was a cross-sectional study of 34 samples of atopic dermatitispatients attending the skin clinic of Hospital Universiti Sains Malaysia (HUSM) and Hospital Raja Perempuan Zainab II (HRPZ II), Malaysia. 34 samples of normal controls were taken from healthy people (those who were free from allergic history) in HUSM. The subjects of healthy controls and atopic dermatitis patients were defined through history taking by physician. $5 \mathrm{ml}$ of blood were collected from the normal control subjects and patients. Then, the blood was centrifuged and analyzed for IL 31 using ELISA kits (Human IL 31 Duoset, RnD System). Independent T-test was used to compare the level of serum IL 31 betweennormal control subjects and patients with atopic dermatitis.

\section{Results}

The result showed that there was no significant difference in IL 31 serum levels between non allergic (174.89 \pm 33.08, $\mathrm{n}=34, \mathrm{p}=0.082$ ) and atopic dermatitis patients

${ }^{1}$ Universiti Sains Malaysia, Malaysia

Full list of author information is available at the end of the article
(16499.46 $\pm 9243.56, \mathrm{n}=34)$. However, there was a trend towards a higher IL31 serum levels in atopic dermatitis patients.

\section{Conclusions}

The results of this study suggest that although the level of IL31 serum levels was higher, there was no significant difference in IL 31 serum levels between atopic dermatitis patients and non allergic control.

Author details

${ }^{1}$ Universiti Sains Malaysia, Malaysia. ${ }^{2}$ Hospital Raja Perempuan Zainab II, Malaysia.

Published: 23 April 2013

\section{doi:10.1186/1939-4551-6-S1-P62}

Cite this article as: Mohd Ashari et al:: Mechanisims of asthma and allergic disease - 1064. Interleukin 31 (IL 31) serum levels in atopic dermatitis patients. World Allergy Organization Journal 2013 6(Suppl 1):P62.

Submit your next manuscript to BioMed Central and take full advantage of:

- Convenient online submission

- Thorough peer review

- No space constraints or color figure charges

- Immediate publication on acceptance

- Inclusion in PubMed, CAS, Scopus and Google Scholar

- Research which is freely available for redistribution 